\title{
Respiratory infections and coinfections: geographical and population patterns
}

\author{
Norvell Perezbusta-Lara, Rocío Tirado-Mendoza* and Javier R. Ambrosio-Hernández \\ Universidad Nacional Autónoma de México, Faculty of Medicine, Department of Microbiology y Parasitology, Mexico City, Mexico
}

\begin{abstract}
Introduction: Acute respiratory infections are the second cause of mortality in children younger than five years, with 150.7 million episodes per year. Human orthopneumovirus (hOPV) and metapneumovirus (hMPV) are the first and second causes of bronchiolitis; type 2 human orthorubulavirus (hORUV) has been associated with pneumonia in immunocompromised patients. Objective: To define hOPV, hMPV and hORUV geographical distribution and circulation patterns. Method: An observational, prospective cross-sectional pilot study was carried out. Two-hundred viral strains obtained from pediatric patients were genotyped by endpoint reverse transcription polymerase chain reaction (RT-PCR). Results: One-hundred and eighty-six positive samples were typed: 84 hOPV, 43 hMPV, two hORUV and 57 co-infection specimens. Geographical distribution was plotted. hMPV, hOPV, and hORUV cumulative incidences were $0.215,0.42$, and 0.01 , respectively. Cumulative incidence of $h M P V-h O R U V$ and hMPV-hOPV coinfection was 0.015 and 0.23; for hOPV-hMPV-hORUV, 0.035; and for hORUV-hOPV, 0.005. The largest number of positive cases of circulating or co-circulating viruses occurred between January and March. Conclusions: This study successfully identified circulation and geographical distribution patterns of the different viruses, as well as of viral co-infections.
\end{abstract}

KEY WORDS: Acute respiratory infections. Human respiratory viruses. Viral coinfections. Circulation patterns.

\section{Infecciones y coinfecciones respiratorias: patrón geográfico y de circulación poblacional}

\section{Resumen}

Introducción: Las infecciones respiratorias agudas constituyen la segunda causa de mortalidad en los niños menores de cinco años, con 150.7 millones de episodios anuales. Entre los principales agentes etiológicos están Orthopneumovirus (hOPV) y metapneumovirus (hMPV) humanos como primera y segunda causa de bronquiolitis, respectivamente; Orthorubulavirus humano tipo 2 (hORUV) se ha asociado a neumonía en pacientes inmunocomprometidos. Objetivo: Definir patrones de distribución geográfica y de circulación de hOPV, hMPV y hORUV. Método: Se llevó a cabo un estudio piloto transversal prospectivo observacional. Se genotipificaron 200 aislamientos virales de pacientes pediátricos mediante transcripción inversa seguida de reacción en cadena de la polimerasa en punto final (RT-PCR). Resultados: Se tipificaron 186 muestras positivas: 84 de hOPV, 43 de hMPV, dos de hORUV y 57 de coinfecciones. Se trazó la distribución geográfica. Las incidencias acumuladas de hMPV, hOPV y hORUV fueron de 0.215, 0.42 y 0.01, respectivamente. Las incidencias acumuladas de la coinfección de hMPV-hORUV y hMPV-hOPV fueron de 0.015 y 0.23; de hOPV-hMPV-hORUV, de 0.035; y de hORUV-hOPV, de 0.005. El mayor número de casos positivos de virus circulantes o cocirculantes se presentó entre enero y marzo. Conclusiones: Fue posible identificar patrones de circulación y distribución geográfica de los diferentes virus, así como de las coinfecciones virales.

PALABRAS CLAVE: Infecciones respiratorias agudas. Virus respiratorios humanos. Coinfecciones virales. Patrones de circulación. 


\section{Introduction}

Among its objectives, the World Health Organization seeks to reduce mortality in children younger than five years by two thirds, which currently amounts to 8.8 million per year; $37 \%$ occurs within the first month of life and $43 \%$ is associated with infectious diseases, including pneumonia, which is responsible for $14 \%,{ }^{1}$ with 1.9 million deaths and 156 million episodes per year worldwide. ${ }^{2-4}$

Acute respiratory infections (ARI) are one of the main causes of morbidity and mortality, both in neonates and infants. ${ }^{5}$ Etiological agents include bacteria and viruses, such as human type 2 orthopneumovirus (hOPV), human orthorubulavirus (hORUV) and emerging viruses such as human metapneumovirus (hMPV). ${ }^{6}$ The World Health Organization estimates that approximately $25 \%$ of hospitalizations in children are due to acute respiratory infections. hOPV ${ }^{7}$ is responsible for $80 \%$ of this type of infections, followed by hMPV. These agents circulate in the pediatric population throughout the year; however, from December to February there is an increase in the incidence of respiratory pathologies of infectious origin in children younger than five years. Premature newborns and infants with asthma, congenital heart disease or bronchopulmonary dysplasia are more susceptible to these infections, the clinical presentation of which is usually more severe in comparison with that observed in children without comorbidities. ${ }^{8}$

In Mexico, acute lower respiratory tract infections are the leading cause of childhood morbidity due to infectious diseases, and are reported among the top 10 causes of death in children between one and four years of age..$^{9,10}$ The diagnosis is established according to the clinical practice guidelines, which describe that these infections usually occur with cough, wheezing, rales, shortness of breath and, in some cases, respiratory failure that causes death. ${ }^{11}$

Despite the impact of these infections in the world, in Mexico there is no epidemiological surveillance network that provides information on the circulation patterns of these viruses, the incidence of viral coinfections, or their impact on clinical manifestations. ${ }^{12}$ Viral coinfections are associated with an increase in childhood morbidity and mortality and cause "atypical" clinical presentations, which makes correct diagnosis and etiologic agent identification difficult, hence the contradictory results regarding the incidence and severity of ARI when viral infections coexist. ${ }^{12-14}$

Due to the above, establishing the incidence of viral coinfections in pediatric patients with ARIs was proposed, for which molecular diagnosis by reverse transcription followed by endpoint polymerase chain reaction (RT-PCR), previously standardized in the laboratory, was implemented, which allowed the identification and genotyping of 200 viral isolates, as well as determining the incidence of viral infections or coinfections, virus circulation patterns and their geographical distribution. Cumulative incidences were as follows: hMPV, 0.215; hMPV-hORUV, 0.015 and hMPV-hOPV, 0.23; hOPV, 0.42; hMPV-hORUV-hOPV, 0.035; hORUV-hMPV, 0.005; hORUV, 0.01. With these data, generating a circulation pattern outline for the different viruses, as well as for viral co-infections caused by hOPV, hMPV and hORUV, was possible.

\section{Method}

After informed consent letter was obtained, between August 30, 2004 and February 13, 2014, 200 pharyngeal and nasopharyngeal exudate samples were obtained from pediatric patients ( 0 to 14 years of age) with acute respiratory infection. The project was reviewed and approved by the Research and Ethics Commission of the Faculty of Medicine, National Autonomous University of Mexico (project approval 089/2014, registry code FMED/CI/SPLR/134/2014).

From the viral isolates obtained from the clinical samples, identification and determination of the viral group and subgroup was carried out using oligonucleotides designed in the laboratory (Table 1). For amplification of the viral gene of interest, a thermocycler (iCycler ${ }^{\mathrm{TM}}$, Bio-Rad, California, USA) was used with the parameters observed in Figure 1, where $X$ represents the specific alignment temperature of each oligonucleotide. Phase 2 is repeated in 35 cycles.

The SPSS version 19 program was used for data statistical analysis. The samples were considered valid when all the information was available: clinical presentation data, patient history and diagnosis, state of origin of the sample and date of collection, identification of viral infection or coinfection. Samples in which any of these data was not available were considered as "lost" elements.

\section{Results}

\section{Viral typing and viral coinfection cumulative incidence}

Viral isolates were genotyped by endpoint RT-PCR; out of 200 clinical samples, 186 were positive for one 


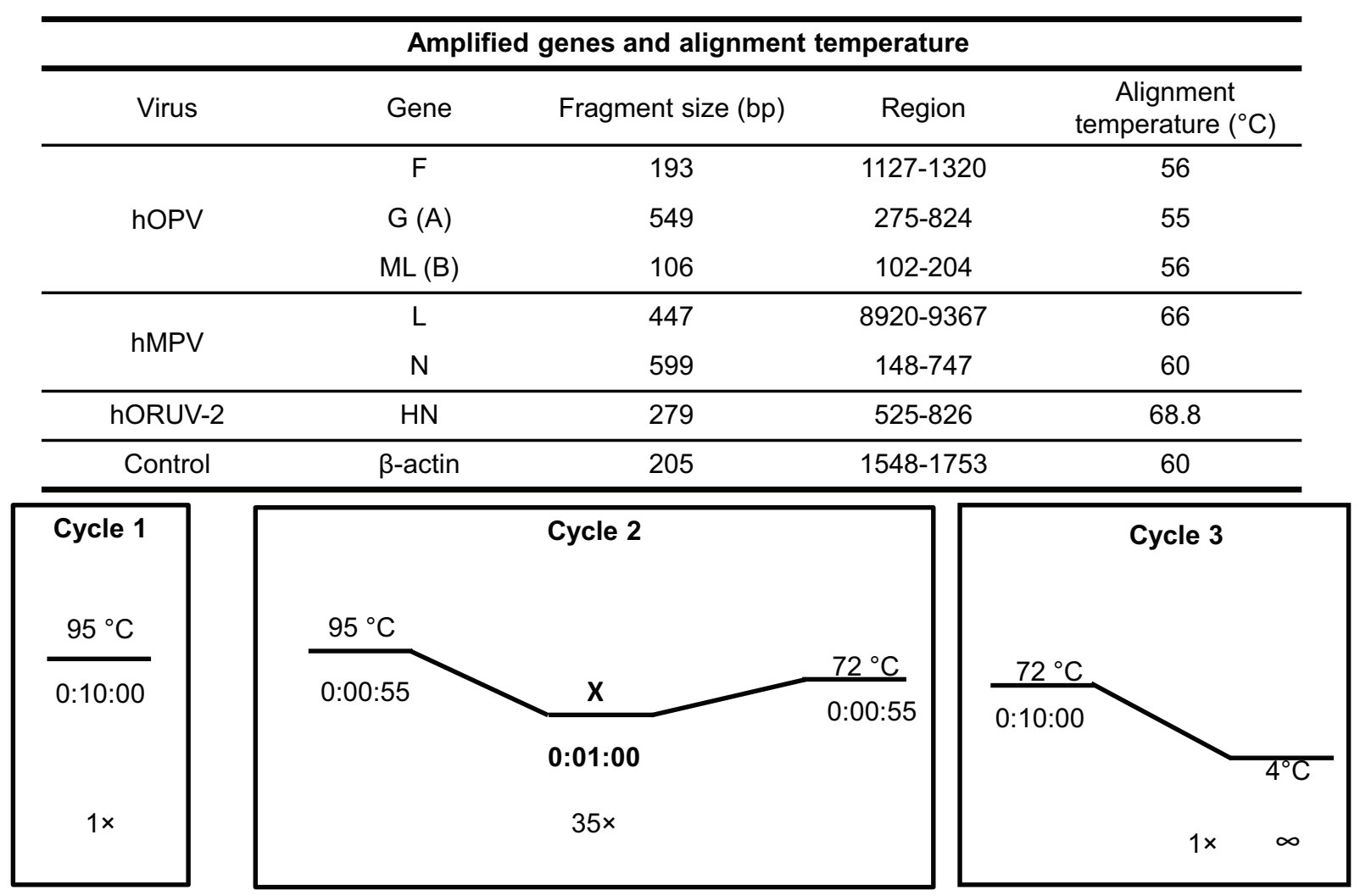

Figure 1. Viral genes amplification. Cycle 1. cDNA denaturation for each of the viruses. Cycle 2. Amplification of the selected region flanked by each pair of oligonucleotides. $X$ represents the alignment temperature of each pair of oligonucleotides selected for each viral gene sequence. The last phase of this cycle corresponds to extension time; this cycle is repeated 35 times (35x). Cycle 3. Corresponds to an extra cycle of the oligonucleotide extension phase on its tempered strand. The last phase corresponds to amplification product maintenance. hOPV $=$ human orthopneumovirus, $h M P V=$ human metapneumovirus, hORUV = type 2 human orthorubulavirus.

Table 1. Oligonucleotide sequences for genotyping of viral isolates obtained from clinical samples of children with acute respiratory infection

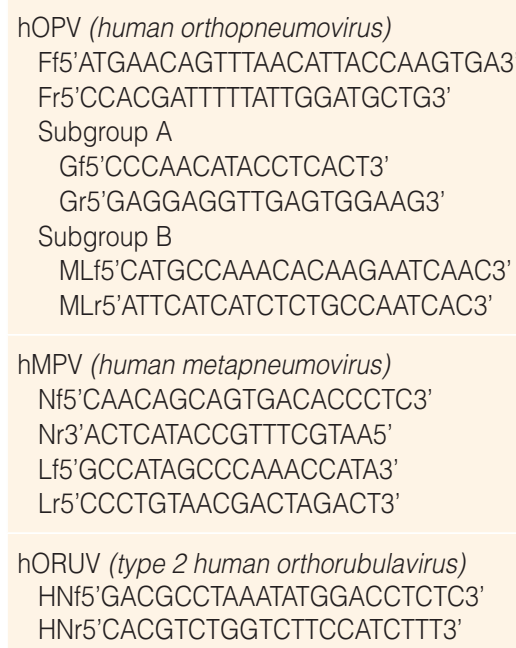

hOPV. $\mathrm{F}$ gene 1127-1320 region amplification ( $F f=$ sense, $\mathrm{Fr}=$ antisense)

Subgroup A. G gene 275-524 region amplification. ( $G f=$ sense, $G r=$ antisense).

Subgroup B. ML gene 102-204 region amplification. (MLf = sense, MLr = antisense).

hMPV. N gene 148-747 region amplification ( $\mathrm{Nf}=$ sense, $\mathrm{Nr}=$ antisense) and $\mathrm{L}$ gene 8920-9367 region amplification ( $L f=$ sense, $L r=$ antisense).

hORUV. HN gene 525-826 region amplification ( $\mathrm{HNf}=$ sense, $\mathrm{HNr}=$ antisense). or more of the three studied viruses and 14 were negative. In the studied pediatric population, hOPV and hMPV cumulative incidences were 0.42 and 0.215 (84 and 43 positive samples, respectively). Regarding cumulative incidence of viral coinfections, it is important to highlight that subgroup B hMPV-hOPV coinfection was the one with the highest incidence, with 24 positive cases. If coinfection by two or more viruses or viral subgroups (hOPV, hMPV and hORUV) is considered rather than the subtype or the amplified gene, hMPV-hOPV coinfection was the one with the highest incidence, with 47 positive cases (23\%), in contrast with hOPV-hORUV and hMPV-hORUV coinfections, which corresponded to two positive cases each (1\%), and hOPV-hORUV-hMPV, with five positive cases (2.5\%) (Table 2).

hOPV-positive clinical samples by amplification of the fragment corresponding to the $F$ gene were subtyped in subgroups $A$ and $B$. For subgroup $A$, a fragment of the gene that codes for glycoprotein $G$, and for subgroup $B$, a fragment of the gene that codes for 
Table 2. Typing and cumulative incidence of viral infections and coinfections with hOPV, hMPV and hORUV in 200 clinical samples of children with acute respiratory infection

\begin{tabular}{|l|c|c|c|c|c|c|c|}
\hline hOPV & hMPV & hORUV & hOPV-hMPV & hOPV-hORUV & hMPV-hORUV & hOPV-hMPV-hORUV & Unidentified \\
\hline $84^{*}$ & $43^{*}$ & $2^{*}$ & $46^{*}$ & $1^{*}$ & $3^{*}$ & $7^{*}$ & $14^{*}$ \\
\hline $0.42^{* *}$ & $0.215^{* *}$ & $0.01^{* *}$ & $0.23^{* *}$ & $0.005^{* *}$ & $0.0015^{* *}$ & $0.0035^{* *}$
\end{tabular}

${ }^{*}$ Positive samples typed by reverse transcription followed by endpoint polymerase chain reaction (RT-PCR). ${ }^{* *}$ Cumulative incidence of viral infections and coinfections in children with acute respiratory infection. hOPV = human orthopneumovirus, hMPV = human metapneumovirus, hORUV = type 2 human orthorubulavirus.

proteins $\mathrm{M}$ and $\mathrm{L}$. Our results showed that, of the 40 hOPV-positive samples, $48 \%$ corresponded to subgroup B, while $27 \%$ corresponded to subgroup A and $3 \%$ to co-infections by both subgroups. In $22 \%$ of hOPV-positive samples, identifying the viral subgroup was not possible, which could be due to probable mutations in subgroup A or B amplified regions (Fig. 2).

\section{Circulation patterns and their distribution in time}

In Mexico, there are no respiratory viruses circulation patterns, incidence of coinfections and geographic distribution available. In addition to the implications on the severity of clinical presentation, it is important to define the incidence of circulation patterns based on seasonality. For this reason, date of collection, chronology of circulation and place of origin of all 136 samples that had this information were determined. The cumulative incidence results showed that the largest number of positive cases of circulating or co-circulating viruses occurred from January to March (Fig. 3), which is consistent with the seasonality of these viruses; however, identifying viruses circulating or co-circulating between April and September, a period that corresponds to the rainy season in Mexico, was possible, although cumulative incidence was actually lower, which is consistent with reports from other countries.

\section{Viral coinfection geographic maps according to cumulative incidence}

The determination of cumulative incidence allowed to draw geographic maps related to the circulation patterns of the study population and to determine the flow of respiratory viruses in different states of Mexico (Fig. 4). Similarly, the geographic circulation pattern was established in hOPV-positive viral isolates, subtyped in A or B (Fig. 5).

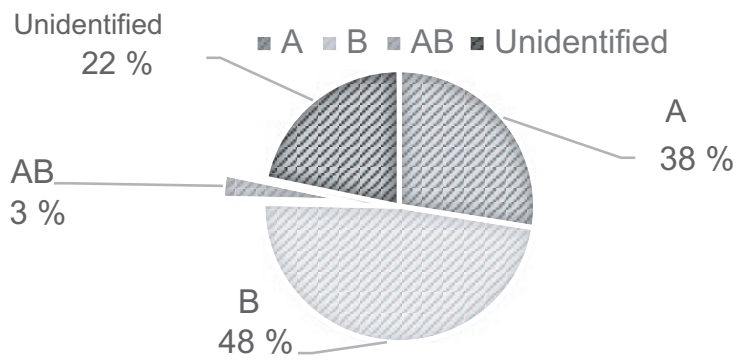

Figure 2. Typing of human orthopneumovirus viral isolates in subgroups $A$ and B; it was carried out by RT-PCR (reverse transcription followed by polymerase chain reaction) at endpoint, and amplification products were observed on Gelred ${ }^{\circledR}$-stained agarose gel. The amplification products were processed and analyzed with the Quantity One Bio-Rad program of ChemiDoc Hood II.

\section{Discussion}

In this project, 200 clinical samples from pediatric patients with acute respiratory infection were analyzed. Our research is a prospective, observational, cross-sectional pilot study, which ran from August 30, 2004 to February 13, 2014. Each sample was obtained with written authorization and after information was provided to the parents or legal guardians. Cumulative incidence, which is a measure of the dynamic index associated with the appearance of new "cases" over time and in the selected population, was determined. hOPV, hMPV and hORUV infection and coinfection cumulative incidence was defined based on 200 viral isolates; with these data, circulation patterns and geographic distribution with regard to seasonality were drawn. Cumulative incidence data for infections associated with a single virus showed that the most frequent was hOPV, with an incidence of $0.42,48 \%$ corresponded to subtype $\mathrm{B}$, and $38 \%$, to $\mathrm{A}$. This result is consistent with reports of subgroup $B$ prevalence in different Chinese populations during the 2009-2010, 2012-2013 and 2006-2014 outbreaks, ${ }^{15,16}$ out of which BA9 and GB5 had the highest circulation. ${ }^{16,17}$ 


\begin{tabular}{|c|c|c|c|}
\hline ahOPV $(\mathrm{F})(\mathrm{A})$ & $\mathrm{hMPV}(\mathrm{N}$ and $\mathrm{L})$ and $\mathrm{hORUV}$ & wMPV $(\mathrm{N}$ and $\mathrm{L})$ & a hMPV $(\mathrm{N})$ and hOPV $(\mathrm{B})$ and hOPV (F) \\
\hline hOPV (A) & a hOPV $(\mathrm{F})(\mathrm{A}$ and $\mathrm{B})$ and $\mathrm{hMPV}(\mathrm{N})$ & Negative for three viruses & hOPV (F) \\
\hline ahORUV & $\mathrm{hOPV}(\mathrm{F})(\mathrm{A}$ and $\mathrm{B})$ & a hOPV $(\mathrm{F})(\mathrm{B})$ & ahORUV and hOPV F) and hMPV (N) \\
\hline hORUV and hOPV (A) & aOPV (B) & hOPV $(\mathrm{F})(\mathrm{A})$ and hMPV $(\mathrm{N})$ & hOPV $(\mathrm{F})$ and $\mathrm{hMPV}(\mathrm{N}$ and $\mathrm{L})$ \\
\hline घMPV (L) & a hMPV (N and $\mathrm{L}$ ) and hOPV (B) & a hOPV ( $\mathrm{F}$ and $\mathrm{B}$ ) and hMPV ( $\mathrm{N}$ and $\mathrm{L})$ & hORUV and hOPV $(\mathrm{F}$ and $\mathrm{B})$ y hMPV $(\mathrm{N})$ \\
\hline a hOPV ( $\mathrm{F}$ and $\mathrm{B})$ and hORUV & a hORUV and hOPV (F and $\mathrm{A})$ and $\mathrm{hMPV}(\mathrm{N})$ & hOPV $(\mathrm{F})$ and $\mathrm{hMPV}(\mathrm{L})$ & hMPV $(\mathrm{L})$ and hOPV(B) \\
\hline
\end{tabular}
40

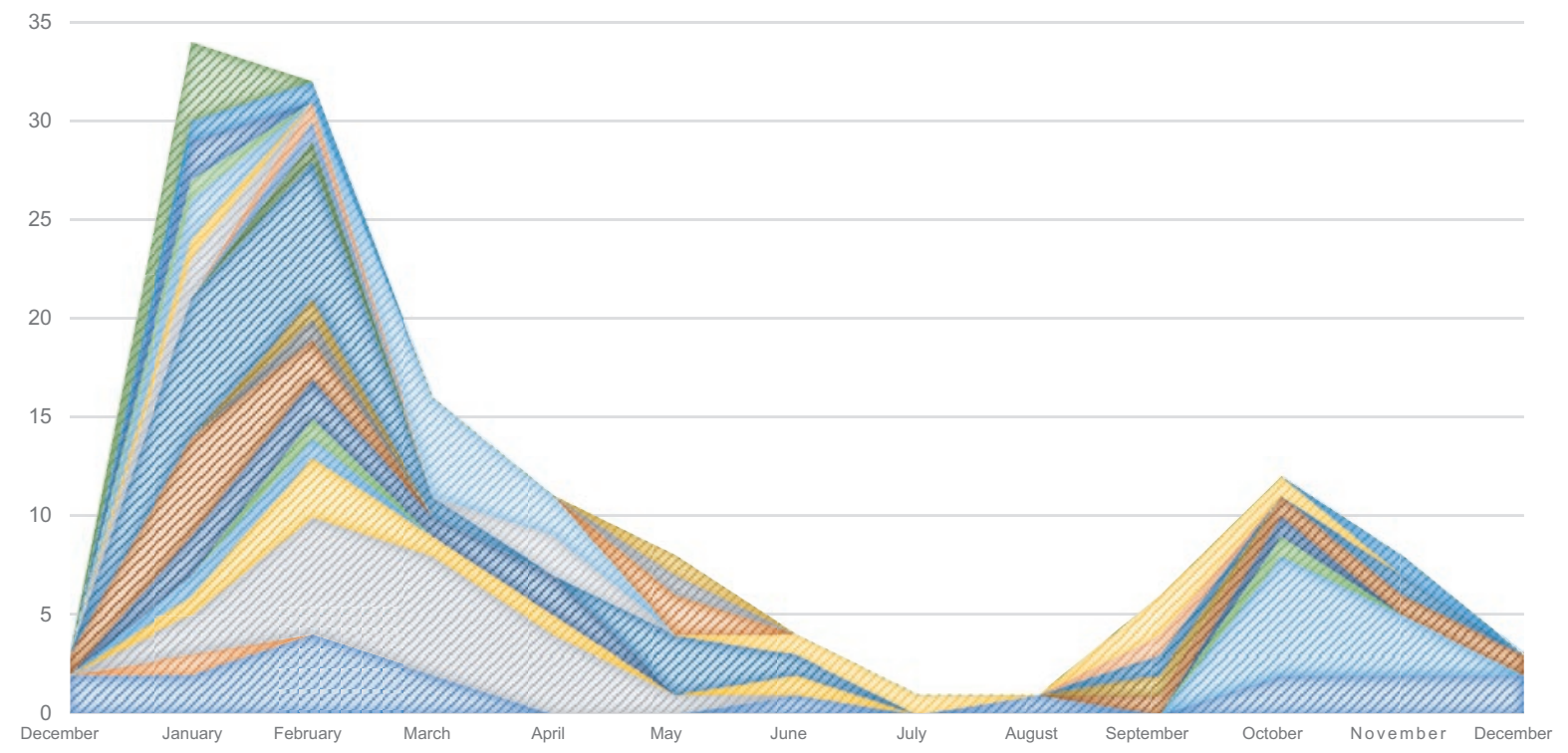

Figure 3. Cumulative incidence and its relationship with weather seasonality. The cumulative incidence of the cases typed as positive for each viral infection and coinfection was determined and was related to the date of sample collection in order to establish circulation patterns and their weather seasonality. hOPV =human orthopneumovirus, hMPV = human metapneumovirus, hORUV = type 2 human orthorubulavirus.

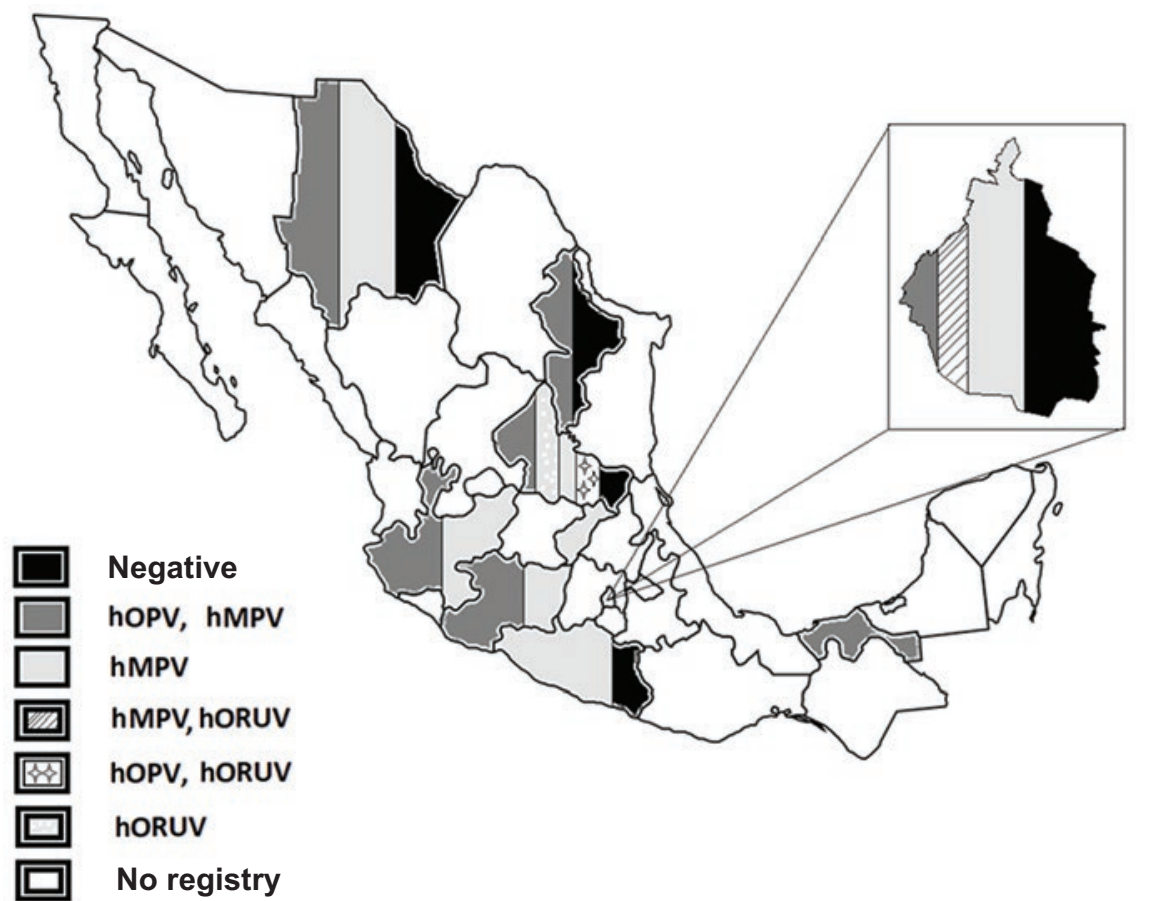

Figure 4. Viral infections and coinfections geographical distribution in Mexico based on viral isolates obtained from 200 samples of pharyngeal and nasopharyngeal exudates from pediatric patients. hOPV =human orthopneumovirus, $h M P V=$ human metapneumovirus, hORUV = type 2 human orthorubulavirus. 


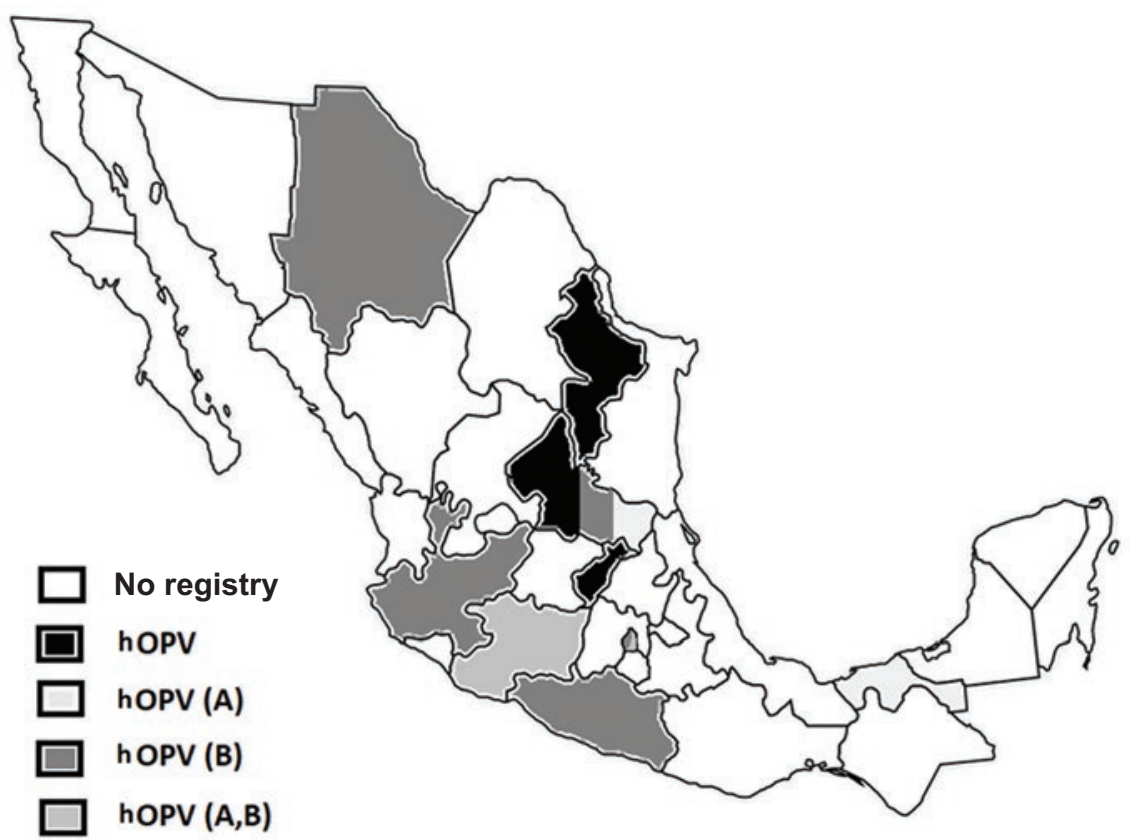

Figure 5. hOPV-positive cases viral subgroups geographical distribution in Mexico determined based on cumulative incidence data. Viral isolates typed as hOPV were subtyped into $A$ and B. hOPV =human orthopneumovirus, hMPV = human metapneumovirus, hORUV = type 2 human orthorubulavirus.

Drawing the geographical distribution was also possible: Mexico City, Chihuahua, San Luis Potosí, Jalisco and Guerrero showed the highest number of positive cases for subgroup B hOPV. Subgroups A and B cumulative incidence and seasonality in Chihuahua and San Luis Potosí may be related to the winter period and cold fronts; in Jalisco and Guerrero, the increase in the number of cases is associated with the rainy season, which is produced by the humid currents of the trade winds from both hemispheres in the so-called "intertropical convergence zone". This seasonality pattern was repeated in the other two viruses; however, hMPV geographical distribution was broader: samples were identified in Mexico City, Chihuahua, San Luis Potosí, Querétaro, Jalisco, Michoacán and Guerrero. The circulation patterns of these viruses during the winter season and the rainy season may be associated with the effect of weather on innate immune defense mechanisms in the respiratory system, such as decreased mucociliary movement and impaired ability of the upper respiratory tract to adequately heat cold air, which favors this type of infection. During the rainy season, environmental humidity contributes for saliva droplets to remain suspended for a longer time, which facilitates their dissemination.

Our data are consistent with the report on the predominance of type $A$ and $C$ rhinovirus during the rainy season and early winter. ${ }^{18}$ Furthermore, a retrospective study conducted between 1985 and 1987 in Nigerian children with respiratory infection showed that peak incidence of reported cases occurred in September, in the rainy season, which is followed by the trade wind season in West Africa, characterized by cold, dryness with dust and low humidity from November to March (Harmattan), which are environmental conditions that damage the airways and favor exposure to infections. ${ }^{19-21}$ Our results also agree with the finding that human respiratory coronaviruses $(\mathrm{HCoV})$ are responsible for $\mathrm{ARI}$ during Harmattan and the rainy season. ${ }^{21-23}$

Our results showed that the highest cumulative incidence of viral coinfections occurred in San Luis Potosí (three cases) and Mexico City (two cases); in addition, San Luis Potosí was the only state where hORUV-positive samples were isolated and identified as the only causative agent and in coinfection with hOPV and hMPV. Our investigation allowed to detect viral coinfections also in Chihuahua, Nuevo León, Jalisco, Michoacán and Tabasco. Co-circulation of these respiratory viruses, their seasonal coincidence, and immune system conditions of infected patients favor multiple infections. In another study of our working group, it was concluded that viral coinfections modify respiratory clinical presentation, causing "atypical" manifestations with the appearance of signs and symptoms such as fever, abdominal pain, laryngeal stridor and hyaline 
rhinorrhea, which makes diagnosis and correct identification of the etiological agent difficult. ${ }^{12}$

Finally, our results suggest that pediatric age is a predisposing factor for viral infection, probably because lung maturation is achieved after eight years of age.12 In Mexico, there are no epidemiological data available, probably due to lack of information in patient records (medical-legal documents), which compile patient ailments chronological order and contribute to efficient diagnosis. Without this information, diagnosis becomes random and the factors that determine a disease or the circumstances that facilitate an accurate diagnosis are lost sight of: ${ }^{12}$ in addition, the opportunity to determine viruses circulation patterns is lost.

Recent investigations address viral coinfections and new respiratory symptoms, as well as new health strategies to confront infections and decrease mortality rates in children. ${ }^{12}$ Despite bias due to the number of analyzed samples, the reported incidence of each virus and associated coinfections provided the necessary data to generate an outline of circulation patterns and geographic distribution in Mexico.

\section{Acknowledgements}

Our thanks to Hospital Regional "Adolfo López Mateos", to Universidad Autónoma de San Luis Potosí Faculty of Medicine and to Instituto de Diagnóstico y Referencia Epidemiológicos, for donating the clinical samples. To Antonio Magaña Hernández, for his observations on the manuscript.

\section{Conflict of interests}

The authors declare that they have no conflicts of interest.

\section{Funding}

Project supported by Universidad Autónoma de México General Directorate of Support for Academic Staff (IN224316 and DGAPA PE211115).

\section{Ethical disclosure}

Protection of people and animals The authors declare that no experiments were performed on humans or animals for this research.

Confidentiality of data The authors declare that no patient data appear in this article.
Right to privacy and informed consent The authors obtained informed consent from the legal guardians of the children referred to in the article. The document is in the possession of the corresponding author.

\section{References}

1. World Health Organization [Internet]. Switzerland: Pneumonia; 2019

2. Knipe D, Howley P. Fields virology. Volume 2. USA: Lippincott Williams \& Wilkins; 2007.

3. Hall CB, Simőes EA, Anderson LJ. Clinical and epidemiologic features of respiratory syncytial virus. Curr Top Microbiol Immunol. 2013: 372:39-57.

4. Wertz GW, Moudy RM. Antigenic and genetic variation in human respiratory syncytial virus. Pediatr Infect Dis J. 2004;23:19-24.

5. Bezerra PGM, Britto MCA, Correia JB, Duarte MC, Fonceca AM, Rose $\mathrm{K}$, et al. Viral and atypical bacterial detection in acute respiratory infection in children under five years. PLoS One. 2011:6:4-12.

6. García-García ML, Calvo C, Rey C, Díaz B, Del Mar-Molinero M, Pozo F, et al. Human metapneumovirus infections in hospitalized children and comparison with other respiratory viruses. 2005-2014 prospective study. PLoS One. 2017:12:e0173504.

7. Price RHM, Graham C, Ramalingam S. Association between viral seasonality and meteorological factors. Sci Rep. 2019:9:1-11.

8. Manzoni $P$, Figueras-Aloy J, Simões EAF, Checchia PA, Fauroux B, Bont $L$, et al. Defining the incidence and associated morbidity and mortality of severe respiratory syncytial virus infection among children with chronic diseases. Infect Dis Ther. 2017:6:383-411.

9. Secretaría de Salud. Anuarios de morbilidad 1984-2018. Mexico: SSa; 2020

10. Wong-Chew RM, García-León ML, Noyola DE, Pérez-González LF, Gaitán-Meza J, Villaseñor-Sierra A, et al. Respiratory viruses detected in Mexican children younger than 5 years old with community-acquired pneumonia: A national multicenter study. Int J Infect Dis. 2017;62:32-38.

11. Instituto Mexicano del Seguro Social. Guía de práctica clínica de diagnóstico y tratamiento de bronquiolitis aguda en niñas/niños y en el primer nivel de atención. Mexico: Instituto Mexicano del Seguro Social/Secretaría de Salud; 2015.

12. Hernández D. Estudio piloto de infecciones respiratorias agudas en coinfecciones virales (virus sincitial respiratorio y metapneumovirus humano y su impacto en las manifestaciones clínicas, diagnósticas y epidemiológicas. Contacto Químico. 2016;16:11-13.

13. Robledo-Aceves M, Moreno-Peregrina MJ, Velarde-Rivera F, Ascencio-Esparza E, Preciado-Figueroa F, Escobedo-Meléndez G, et al. Risk factors for severe bronchiolitis caused by respiratory virus infections among Mexican children in an emergency department. Medicine (Baltimore). 2018;97:9

14. Díaz J, Morales-Romero J, Pérez-Gil G, Bedolla-Barajas M, Delgado-Figueroa N, García-Román R, et al. Viral coinfection in acute respiratory infection in Mexican children treated by the emergency service: A cross-sectional study. Ital J Pediatr. 2015;4:33.

15. Ren L, Xiao Q, Zhou L, Xia Q, Liu E. Molecular characterization of human respiratory syncytial virus subtype B: a novel genotype of subtype $B$ circulating in China. J Med Virol. 2015;87:1-9.

16. Song J, Wang H, Shi J, Cui A, Huang $Y$, Sun L, et al. Emergence of BA9 genotype of human respiratory syncytial virus subgroup B in China from 2006 to 2014. Sci Rep. 2017;7:16765.

17. Fan R, Fan C, Zhang J, Wen B, Lei Y, Liu C, et al. Respiratory syncytial virus subtype ON1/NA1/BA9 predominates in hospitalized children with lower respiratory tract infections. J Med Virol. 2017;89:213-221.

18. Matthew J, Pinto-Pereira LM, Pappas TE, Swenson CA, Grindle KA, Roberg KA, et al. Distribution and seasonality of rhinovirus and other respiratory viruses in a cross-section of asthmatic children in Trinidad, West Indies. Ital J Pediatr. 2009;35:1-10.

19. Olaleye OD, Omilabu SA, Olabode AO, Fagbami AH. Serological evidence for influenza virus activity in Nigeria (1985-1987). Virologie. 1989:40:11-17.

20. Maïnassara HB, Lagare A, Tempia S, Sidiki A, Issaka B, Abdou Sidikou B, et al. Influenza sentinel surveillance among patients with influenza-like-illness and severe acute respiratory illness within the framework of the $\mathrm{Na}$ tional Reference Laboratory, Niger, 2009-2013. PLoS One. 2015;10:1-9.

21. Owusu M, Annan A, Corman VM, Larbi R, Anti P, Drexler JF, et al. Human coronaviruses associated with upper respiratory tract infections in three rural areas of Ghana. PLoS One. 2014:9:24-27.

22. Talla-Nzussouo N, Duque J, Adedeji AA, Coulibaly D, Sow S, Tarnagda Z, et al. Epidemiology of influenza in West Africa after the 2009 influenza A(H1N1) pandemic, 2010-2012. BMC Infect Dis. 2017:17:1-8.

23. Dia N, Sarr FD, Thiam D, Sarr TF, Espié E, OmarBa I, et al. Influenza-like illnesses in Senegal: not only focus on influenza viruses. PLoS One. 2014:9:e93227. 